\title{
Adsorption of Indigo Carmine Dye by Composite Activated Carbons Prepared from Plastic Waste (PET) and Banana Pseudo Stem
}

\author{
Baissassou Debina', Sakué Ngankam Eric, Daniel Fotio', Kamdem Tamo Arnaud ${ }^{2}$, \\ Dai-Yang Lemankreo', Abdoul Ntieche Rahman ${ }^{3 *}$ \\ ${ }^{1}$ Department of Chemistry, Faculty of Science, University of Maroua, Maroua, Cameroon \\ ${ }^{2}$ Department of Chemistry, Faculty of Science Semlalia, University of Cady Ayyad, Marrakech, Morocco \\ ${ }^{3}$ Department of Chemistry, Higher Teachers' Training College of Bertoua, University of Ngaoundéré, Yaounde, Cameroon \\ Email: ^rahmino@gmail.com
}

How to cite this paper: Debina, B., Eric, S.N., Fotio, D., Arnaud, K.T., Lemankreo, D.-Y. and Rahman, A.N. (2020) Adsorption of Indigo Carmine Dye by Composite Activated Carbons Prepared from Plastic Waste (PET) and Banana Pseudo Stem. Journal of Materials Science and Chemical Engineering, 8, 39-55.

https://doi.org/10.4236/msce.2020.812004

Received: October 3, 2020

Accepted: December 20, 2020

Published: December 23, 2020

Copyright $\odot 2020$ by author(s) and Scientific Research Publishing Inc. This work is licensed under the Creative Commons Attribution International License (CC BY 4.0).

http://creativecommons.org/licenses/by/4.0/

\begin{abstract}
This study is on the adsorption of indigo carmine dye by composite activated carbons prepared from banana pseudo stems and plastic waste. The activated carbons named $\mathrm{TB}_{1} \mathrm{P}_{1}, \mathrm{~TB}_{1} \mathrm{P}_{1 \mathrm{~h}}$ and $\mathrm{TB}_{2} \mathrm{P}_{1}$ were obtained by pyrolysis at $700^{\circ} \mathrm{C}$ under steam of raw materials at different ratios (1:1 and 2:1). They were characterized by different techniques such as SEM/EDX, Raman Spectroscopy, FTIR, XRD, TGA/DTA and BET/BJH. Analyses indicate amorphous structures with specific surface areas of $424.37 ; 385.45$ and $338.84 \mathrm{~m}^{2} / \mathrm{g}$ for $\mathrm{TB}_{1} \mathrm{P}_{1}$, $\mathrm{TB}_{1} \mathrm{P}_{1 \mathrm{~h}}$ and $\mathrm{TB}_{2} \mathrm{P}_{1}$ respectively. The study of the adsorption of indigo carmine dye by these adsorbents was carried out by varying parameters such as contact time, mass of adsorbent and initial concentration of the dye. The maximum retention is $94.71 \%, 86.18 \%$ and $84.17 \%$ for $\mathrm{TB}_{1} \mathrm{P}_{1}, \mathrm{~TB}_{1} \mathrm{P}_{1 \mathrm{~h}}$ and $\mathrm{TB}_{2} \mathrm{P}_{1}$ respectively after $60 \mathrm{~min}$ of stirring, for a $\mathrm{pH}=4.6$ using $0.6 \mathrm{~g}$ of adsorbents. The adsorption of indigo carmine follows well, the Langmuir model, with the most suitable kinetics as pseudo second order.
\end{abstract}

\section{Keywords}

Adsorption, Activated Carbon, Composite, Plastic Waste, Dye

\section{Introduction}

The intensive use of dyes in cosmetic, textile, pharmaceutical, leather, plastic and paper industries [1], makes them among the most abundant pollutants encountered in the environment. Because of their high content of organic matter which is difficult to biodegrade, of suspended matter and even of their coloring, dyes 
spilled into nature generate serious problems for the environment and especially for that of aqueous media [2] [3]. Among these dyes, we can cite indigo carmine used as an additive in pharmacy and as a coloring agent in pastries, confectionery and cosmetics [4] [5]. It belongs to the class of indigo dyes which is very toxic to the environment. Its presence in water reduces the penetration of light, affects photosynthesis of aquatic flora leading to decrease growth of bacteria and hence decreasing the bio-degradation of impurities in water [6] [7]. According to WHO (World Health Organization), the amount of indigo carmine in water should not exceed $0.005 \mathrm{mg} / \mathrm{L}$ [8]. Consumption of water with a concentration higher than the standard can cause damage in humans such as cancer, cardiovascular disease, affect the reproductive system and cause digestive disorders [9] [10] [11].

Faced with the multiple dangers that indigo carmine can cause on the environment, several physicochemical and biological methods have been used for its elimination in aqueous media. We have among others flocculation-coagulation [12]; electrocoagulation [13]; ultra-filtration [14]; electrochemical [15] [16]; photodegradation [17] and adsorption [18] [19]. Most of these techniques, despite being effective, are difficult to implement and expensive for industries. It is for this reason that adsorption is the most used method because it is simple, easy to implement, economical and non-polluting [20]. On the other hand, the materials so far used in the adsorption of indigo carmine vary from one author to another and generally are activated carbon [21], magnesium oxide [22], zeolite [23] and nanofiber membranes [3]. From economic point of view, the process of adsorption onto activated carbon is advantageous due to the plentiful accessibility of low-cost raw material. As a matter of fact, activated carbon, basically referred to as carbonaceous materials, has high physicochemical stability, porosity, sorption capacity and immense surface area [20]. Given these different properties, our research group has for some time set its objective on the preparation of activated carbon using polyethylene terephthalate plastic bottles as well as polyethylene terephthalate/palm kernel waste composites and banana peel for the elimination of pollutants in aqueous media [24]. However, there is little research on the use of plastic waste composite for the preparation of activated carbon used to decontaminate water due to coloring. As is the case, nearly a million plastic bottles are purchased every minute worldwide [25], a large part of which will end up in the ocean, then taking between 100 and 1000 years to degrade depending on the environment in which they are found [26]. To this end, they can cause flooding or be ingested by aquatic animals causing adverse effects on the health of living beings [27].

Activated carbon prepared in combination with the pseudo-trunk of the banana pseudo stem of the genus "musa", has a better yield than that based on PET alone [24], which made subject of our research. Activated carbons named $\mathrm{TB}_{1} \mathrm{P}_{1}$, $\mathrm{TB}_{1} \mathrm{P}_{1 \mathrm{~h}}$ and $\mathrm{TB}_{2} \mathrm{P}_{1}$ were characterized by FTIR, SEM/EDX, TGA/DTA, BET/BJH and XRD. Their performance on the adsorption of indigo carmine was systemi- 
cally studied based on the contact time, initial concentration, mass of the adsorbent, isotherms and adsorption kinetics.

\section{Experimental Section}

\subsection{Reagents and Materials}

Polyethylene terephthalate plastic waste and "Musa" banana pseudo stem were collected from fields and municipal garbage cans, washed, dried, cut into small sizes and used as precursors. Sodium hydroxide $(\mathrm{NaOH}, \geq 99 \%)$ and hydrochloric acid ( $\mathrm{HCl}, 37 \%)$ came from Carlo ERBA. Indigo carmine $\left(\mathrm{C}_{16} \mathrm{H}_{8} \mathrm{~N}_{2} \mathrm{Na}_{2} \mathrm{O}_{8} \mathrm{~S}_{2}\right.$ 98\%) provided by Reactive RAL. All the above chemicals were of analytical grade and used without further purification.

\subsection{Preparation of Activated Carbon}

The activated carbons were prepared by introducing in a 1:1 and 2:1 ratio of the banana tree trunk and plastic waste in tubular ovens, then the mixture was carbonized up to $500^{\circ} \mathrm{C}$ with an evolution of $10^{\circ} \mathrm{C} / \mathrm{min}$ under nitrogen $(0.15$ $\mathrm{mL} / \mathrm{min}$ ) and a total residence time of $120 \mathrm{~min}$. It was subsequently activated by increasing the temperature to $700^{\circ} \mathrm{C}$ (evolution $5^{\circ} \mathrm{C} / \mathrm{min}$ ) while sulmoultaneously spraying water vapor $(0.1 \mathrm{~mL} / \mathrm{min})$ for a residence time of $60 \mathrm{~min}$. Let cool to room temperature. The compounds obtained for 1:1 and 2:1 ratios were respectively named $\mathrm{TB}_{1} \mathrm{P}_{1}$ and $\mathrm{TB}_{2} \mathrm{P}_{1}$. Similarly, the same procedure was followed for the preparation of $\mathrm{TB}_{1} \mathrm{P}_{1 \mathrm{~h}}$ (ratio 1:1) with the only difference of $700^{\circ} \mathrm{C}$ (evolution of $10^{\circ} \mathrm{C} / \mathrm{min}$ ) for $60 \mathrm{~min}$ for activation of the carbonized sample.

\subsection{Characterizations}

Fourier transform infrared (FTIR) analysis was performed using a mixture of $0.09 \mathrm{~g} \mathrm{KBr}$ and $0.01 \mathrm{~g}$ sample which we analyzed on Vertex 70 brand wavelength device (4000 - $400 \mathrm{~nm}$ ) with a resolution of $4 \mathrm{~cm}^{-1}$ (32 scans) to determine functional groups of surfaces. X-ray diffraction on XRD powder (RigakuGeigerflex, $\mathrm{Cu} \mathrm{Ka}, \lambda=1.5406 \mathrm{~A}$ ) produced at $30 \mathrm{kV}$ and $25 \mathrm{~mA}$ scanned the diffraction angles $(2 \theta)$ between $10^{\circ}$ and $80^{\circ}$ with the step size of $0.002^{\circ} 2 \theta$ per second. Elemental EDX analysis performed using EDAX TEAM, $125.9 \mathrm{ev}$ of resolution, to know the composition of the elements present in the material coupled to SEM on a VEGA3 TESCAN brand device to know the surface morphology. Raman spectroscopy to determine the structural and electronic properties of materials performed with a Nano brand SP (Confotec MR-SOL instrument) with the 570 $\mathrm{nm}$ wavelength laser vert. The analysis of the specific surface, the pore volume as well as the particle size distribution was estimated using the BET equation employing the adsorption of $\mathrm{N}_{2}$ at $77.13 \mathrm{~K}$, on a micrometric sorptometer model device (Thermo Electron Corporation, Sorptomatic Advanced Data Processing). After adsorption of $\mathrm{N}_{2}$, the sample was discharged at $307.13 \mathrm{~K}$. The volume and the cumulative surface area of the pores were calculated using the BJH model coupled to the BET. 
TGA/DTA was performed on a branded device (TGA/DTA, NETZSCH STA $409 \mathrm{C} / \mathrm{CD}$ ). Approximately $10 \mathrm{mg}$ of each dried sample was weighed in an aluminum mold and heated to a temperature ranging from $30^{\circ} \mathrm{C}-1500^{\circ} \mathrm{C}(10$ $\mathrm{K} / \mathrm{min}$ ) under nitrogen flow $(2 \mathrm{~mL} / \mathrm{min})$. With the exception of the BET/BJH and TGA/DTA carried out at Freiburger Material for schungszentrum (Germany), all the other analyzes were carried out at the "Centre d'Analyse et de Characterization" Semlalia-Marrakech, Faculty of Sciences of Cadi Ayyad University (Morocco).

\subsection{Adsorption of Indigo Carmine}

The performance of the prepared activated carbon was evaluated on the adsorption of indigo carmine in aqueous solution. $20 \mathrm{~mL}$ of a solution with a concentration of $120 \mathrm{mg} / \mathrm{L}$ of the pollutant was introduced into a $50 \mathrm{~mL}$ bottleinto which an exact mass of the activated carbon is added to the solution and stirred for a given time. The mixture is filtered through filter paper and the concentration of the filtrate is measured using a SECOMAN brand UV-Vis spectrophotometer. The quantities adsorbed as well as the percentage of pollutant elimination are calculated using the formulas:

$$
\begin{aligned}
Q_{a d s} & =\frac{\left(C_{i}-C_{f}\right) \cdot V}{m} \\
Q_{a d s} & =\frac{\left(C_{i}-C_{f}\right) \cdot V}{C_{i} \times 100}
\end{aligned}
$$

$Q_{a d s}:$ Amount of adsorbate per gram of adsorbent $(\mathrm{mg} / \mathrm{g})$,

$C_{i}$ : Initial pollutant concentration $(\mathrm{mg} / \mathrm{L})$,

$C_{f}$ : Residual pollutant concentration $(\mathrm{mg} / \mathrm{L})$,

$m:$ Mass of activated carbon (g),

$V:$ Volume of the solution (L).

\section{Results and Discussions}

\subsection{Characterizations}

The FTIR spectra of the composite activated carbon are shown in Figure 1. The band around $3800-3386 \mathrm{~cm}^{-1}$ corresponds to the $\mathrm{OH}$ elongation vibrations [28]. The peak around $3544.23 \mathrm{~cm}^{-1}$ (on the curve in black) represents the vibration of N-H elongation. We have a less intense peak around $1637 \mathrm{~cm}^{-1}$ and another more intense at $1403.7 \mathrm{~cm}^{-1}$ corresponding to elongation vibrations of $\mathrm{C}=\mathrm{O}$ and $\mathrm{C}=\mathrm{C}$ respectively. These bands move towards shorter wavelengths probably because of intermolecular hydrogen bonds. At $1134 \mathrm{~cm}^{-1}$ we have cellulose and lignite C-O-C present on the activated carbon. Between 999.37 $615.73 \mathrm{~cm}^{-1}$ are vibrations out of the plane of the $\mathrm{C}-\mathrm{H}$ bonds.

Figure 2 shows the Raman spectrum of the prepared activated carbons. All samples have two strong peaks at $1336.14 \mathrm{~cm}^{-1}$ and $1595.39 \mathrm{~cm}^{-1}$. The D band around $1336.14 \mathrm{~cm}^{-1}$ corresponds to the disordered graphitic network. The $\mathrm{G}$ 
band around $1595.39 \mathrm{~cm}^{-1}$ corresponds to the vibration of the C-C bonds of carbon atoms with a graphitic degree [29]. The increase in the intensities of the $\mathrm{G}$ and $\mathrm{D}$ bands indicates an increase in the graphitic degree. Likewise, the decrease in the intensity ratio of the $D$ band to the $G$ band $\left(I_{D} / I_{G}\right)$ indicates an increase in the graphitic degree. According to Figure 2, these ratios are 0.9568; 0.9879 and 0.9022 for the $\mathrm{TB}_{1} \mathrm{P}_{1}, \mathrm{~TB}_{1} \mathrm{P}_{1 \mathrm{~h}}$ and $\mathrm{TB}_{2} \mathrm{P}_{1}$ respectively. These results clearly indicate that some materials have higher graphitic degrees and less disordered structure. However, increasing the graphitic degree of a material can dramatically increase electrical conductivity [30]. So, we can confirm that the material $\mathrm{TB}_{2} \mathrm{P}_{1}$ is more disordered and has a higher electrical conductivity than $\mathrm{TB}_{1} \mathrm{P}_{1 \mathrm{~h}}$ and $\mathrm{TB}_{1} \mathrm{P}_{1}$.

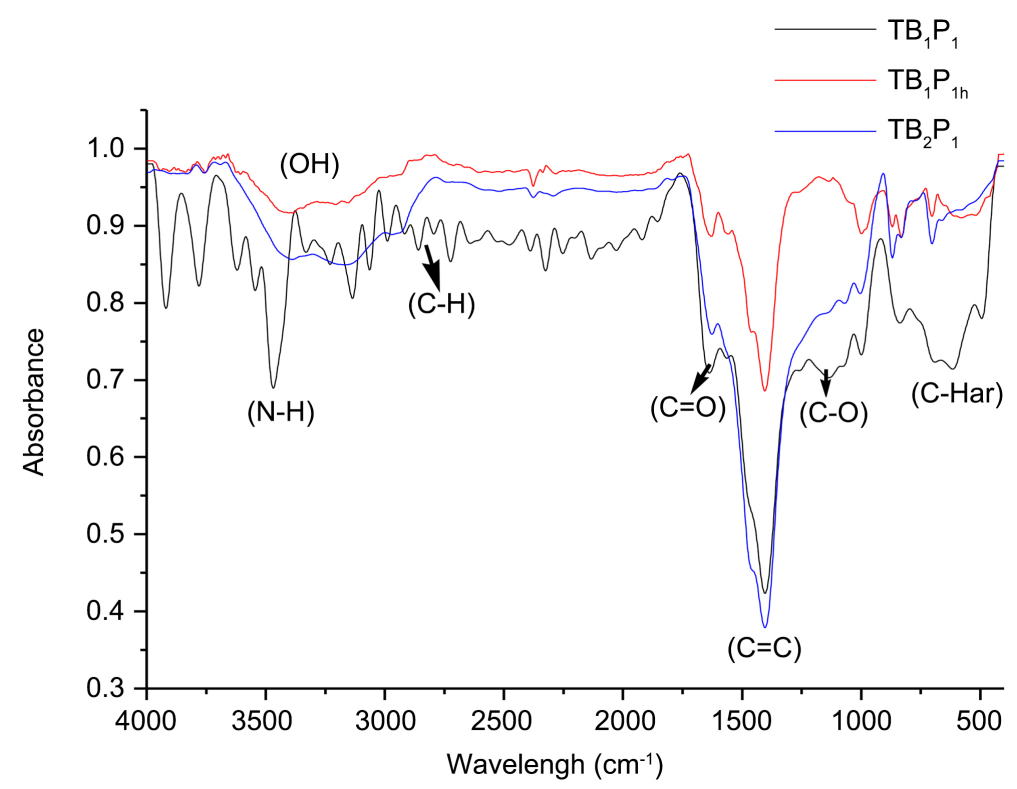

Figure 1. FT-IR spectra of composite carbons $\mathrm{TB}_{1} \mathrm{P}_{1}, \mathrm{~TB}_{1} \mathrm{P}_{1 \mathrm{~h}}$ and $\mathrm{TB}_{2} \mathrm{P}_{1}$ prepared from banana pseudo stems and plastic waste.

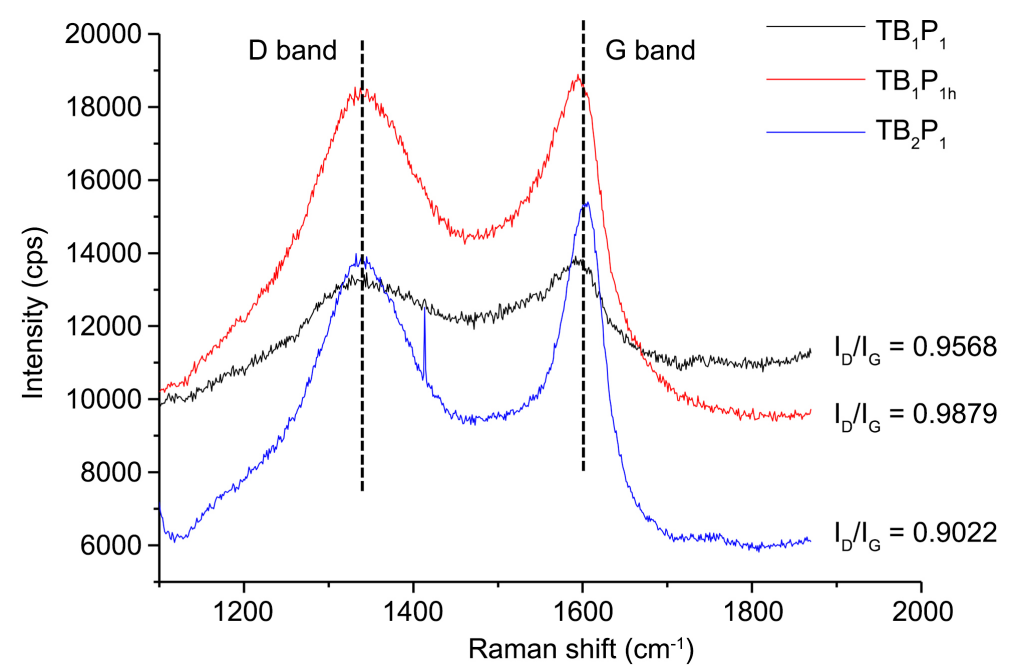

Figure 2. Raman spectrum of composite activated carbons $\mathrm{TB}_{1} \mathrm{P}_{1}, \mathrm{~TB}_{1} \mathrm{P}_{1 \mathrm{~h}}$ and $\mathrm{TB}_{2} \mathrm{P}_{1}$. 
The XRD spectrum of Figure 3 shows several bands, including two larger areas corresponding to the structure of amorphous carbon. The two peaks are at $2 \theta=24.3^{\circ}$ and $2 \theta=44^{\circ}$ respectively correspond to the 002 and 100 reflection planes. In addition to the amorphous character of carbonaceous materials, certain peaks indicate the presence of small amounts of impurity, such as silica at $2 \theta=30^{\circ}$. At $2 \theta=33.88^{\circ}$ we have potassium hydroxide and potassium chloride at $2 \theta=40.72^{\circ}$. These different bands are close to those obtained by Taer et al. in 2018 on activated carbon prepared from banana pseudo stems [31].

Figure 4 shows the adsorption/desorption isotherm of $\mathrm{N}_{2}$ by the different activated carbons. These curves are all the shape of the type IV isotherm according to the IUPAC classification, and the hysteresis loops are in the relative pressure range of 0.4 and 1 , which are characteristic of mesoporous materials [32]. In such a medium, capillary condensation also occurs and the phenomenon is not reversible. The specific surfaces according to BET of the various activated carbons are $424.37 \mathrm{~m}^{2} / \mathrm{g} ; 385.45 \mathrm{~m}^{2} / \mathrm{g}$ and $338.84 \mathrm{~m}^{2} / \mathrm{g}$ for $\mathrm{TB}_{1} \mathrm{P}_{1}, \mathrm{~TB}_{1} \mathrm{P}_{1 \mathrm{~h}}$ and $\mathrm{TB}_{2} \mathrm{P}_{1}$ respectively.

For the three samples, a first very low mass loss is observed in Figure 5 which varies from $5.19 \%$ to $6.14 \%$ in a range of $23.52^{\circ} \mathrm{C}$ to $37.04^{\circ} \mathrm{C}$ which corresponds to humidity rate of these samples. After this phase of dehydration, mass losses of $18.8 \% ; 19.58 \%$ and $20.23 \%$ are observed respectively for $\mathrm{TB}_{1} \mathrm{P}_{1} ; \mathrm{TB}_{2} \mathrm{P}_{1}$ and $\mathrm{TB}_{1} \mathrm{P}_{1 \mathrm{~h}}$ for temperatures between $173.10^{\circ} \mathrm{C}$ and $196.82^{\circ} \mathrm{C}$. Then significant losses are between 35.53 and $41.59 \%$ for temperatures between $794.70^{\circ} \mathrm{C}$ and $961^{\circ} \mathrm{C}$. The mass losses at moderate temperatures would correspond to the decomposition of carboxyl groups $\left(150^{\circ} \mathrm{C}\right.$ and $\left.400^{\circ} \mathrm{C}\right)$, lactone functions between $350^{\circ} \mathrm{C}$ and $600^{\circ} \mathrm{C}$ and phenol functions between $600^{\circ} \mathrm{C}$ and $700^{\circ} \mathrm{C}$ [33].

For DTA, the heat flux values are all negative. This is proof that reactions at the surface of activated carbons are endothermic.

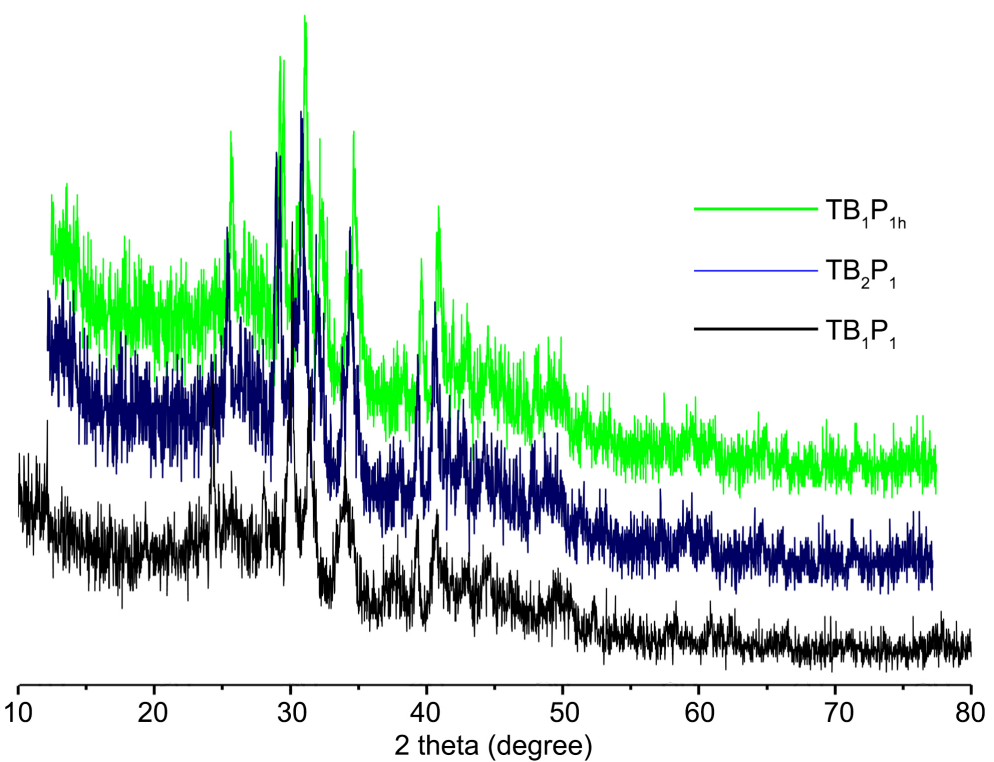

Figure 3. XRD spectrum of composite carbons $\mathrm{TB}_{1} \mathrm{P}_{1}, \mathrm{~TB}_{1} \mathrm{P}_{1 \mathrm{~h}}$ and $\mathrm{TB}_{2} \mathrm{P}_{1}$. 


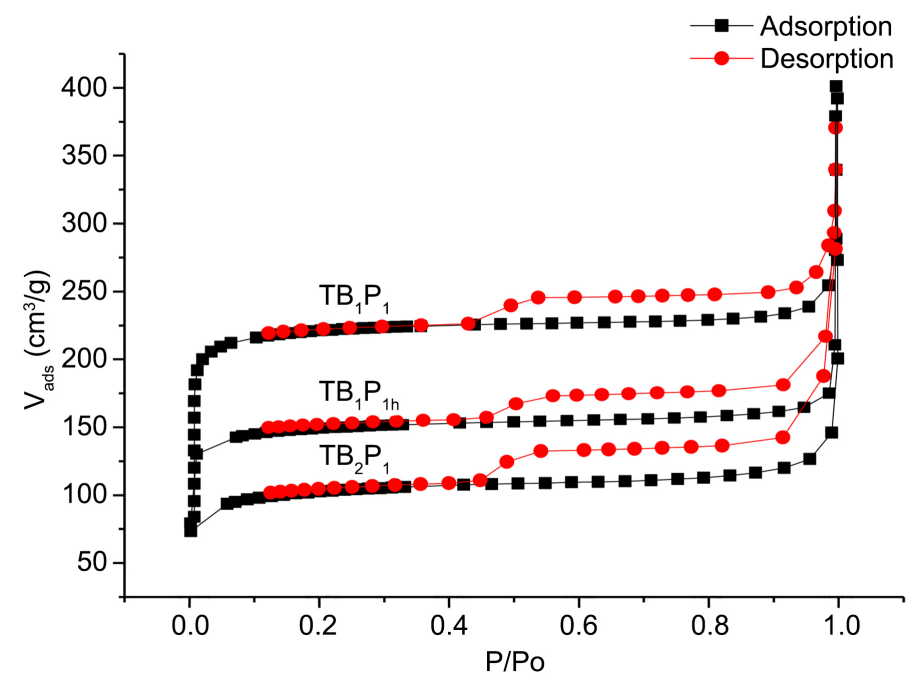

Figure 4. Isotherms of adsorption/desorption of $\mathrm{N}_{2}$ by composite carbons $\mathrm{TB}_{1} \mathrm{P}_{1}, \mathrm{~TB}_{1} \mathrm{P}_{1 \mathrm{~h}}$ and $\mathrm{TB}_{2} \mathrm{P}_{1}$.

\subsection{Study of the Adsorption of Indigo Carmine by Different Activated Carbons}

\subsubsection{Effect of Contact Time on Adsorption}

The time-dependent pollutant removal study in Figure 6 indicates that the curves for $\mathrm{TB}_{1} \mathrm{P}_{1}, \mathrm{~TB}_{2} \mathrm{P}_{1}$ and $\mathrm{TB}_{1} \mathrm{P}_{1 \mathrm{~h}}$ are almost similar. Indeed, the adsorption increases as a function of the stirring time with a rapid effect during the first 60 minutes, before reaching equilibrium at $t \geq 60 \mathrm{~min}$. To this, equilibrium corresponds to an adsorbed quantity of dye of $94.71 \% ; 86.18 \%$ and $84.17 \%$ for $\mathrm{TB}_{1} \mathrm{P}_{1}$, $\mathrm{TB}_{1} \mathrm{P}_{1 \mathrm{~h}}$ and $\mathrm{TB}_{2} \mathrm{P}_{1}$ respectively. It should be noted that the pollutants are adsorbed in the first place on easily accessible sites, with diffusion to less accessible adsorption sites taking place as the stirring time increases until a balance is achieved. As such, at different times of 15, 45 and 75 minutes, we had adsorption rates of $42.28 \%$; $84 \%$ and $94.64 \%$ for $\mathrm{TB}_{1} \mathrm{P}_{1} ; 48.33 \% ; 62.88 \%$ and $81.97 \%$ for $\mathrm{TB}_{1} \mathrm{P}_{1 \mathrm{~h}}$ and $39.87 \% ; 66.89 \%$ and $83.23 \%$ for $\mathrm{TB}_{2} \mathrm{P}_{1}$.

\subsubsection{Effect of Adsorbent Mass}

The effects of mass-dependent indigo carmine removal are shown in Figure 7. In this figure, the mass increase promotes uptake of indigo carmine for all three activated carbons samples. Indeed, for masses $0.2,0.4,0.6,0.8 \mathrm{~g}$ and $1.2 \mathrm{~g}$ of the activated carbons samples, we have the reduction rates of $13.6 \%, 40.98 \%$, 74.94\%. $94.64 \%$ and $94.7 \%$ for $\mathrm{TB}_{1} \mathrm{P}_{1} ; 2.1 \%, 8.89 \%, 17.56 \%, 45.66 \%$ and $86.18 \%$ for $\mathrm{TB}_{1} \mathrm{P}_{1 h}$ and $2.1 \%, 3.28 \%, 17.8 \%, 46.37 \%$ and $89.46 \%$ for the $\mathrm{TB}_{2} \mathrm{P}_{1}$. This increase in adsorption depending on the mass of activated carbon is probably due to the availability of active sites as the mass increases [34]. However, the maximum adsorption is that of sample $\mathrm{TB}_{1} \mathrm{P}_{1}$ which has a larger specific surface area than samples $\mathrm{TB}_{1} \mathrm{P}_{1 \mathrm{~h}}$ and $\mathrm{TB}_{2} \mathrm{P}_{1}$. The more we increase the mass, the more adsorption sites are available for the same amount of pollutant and the greater the absorption. 

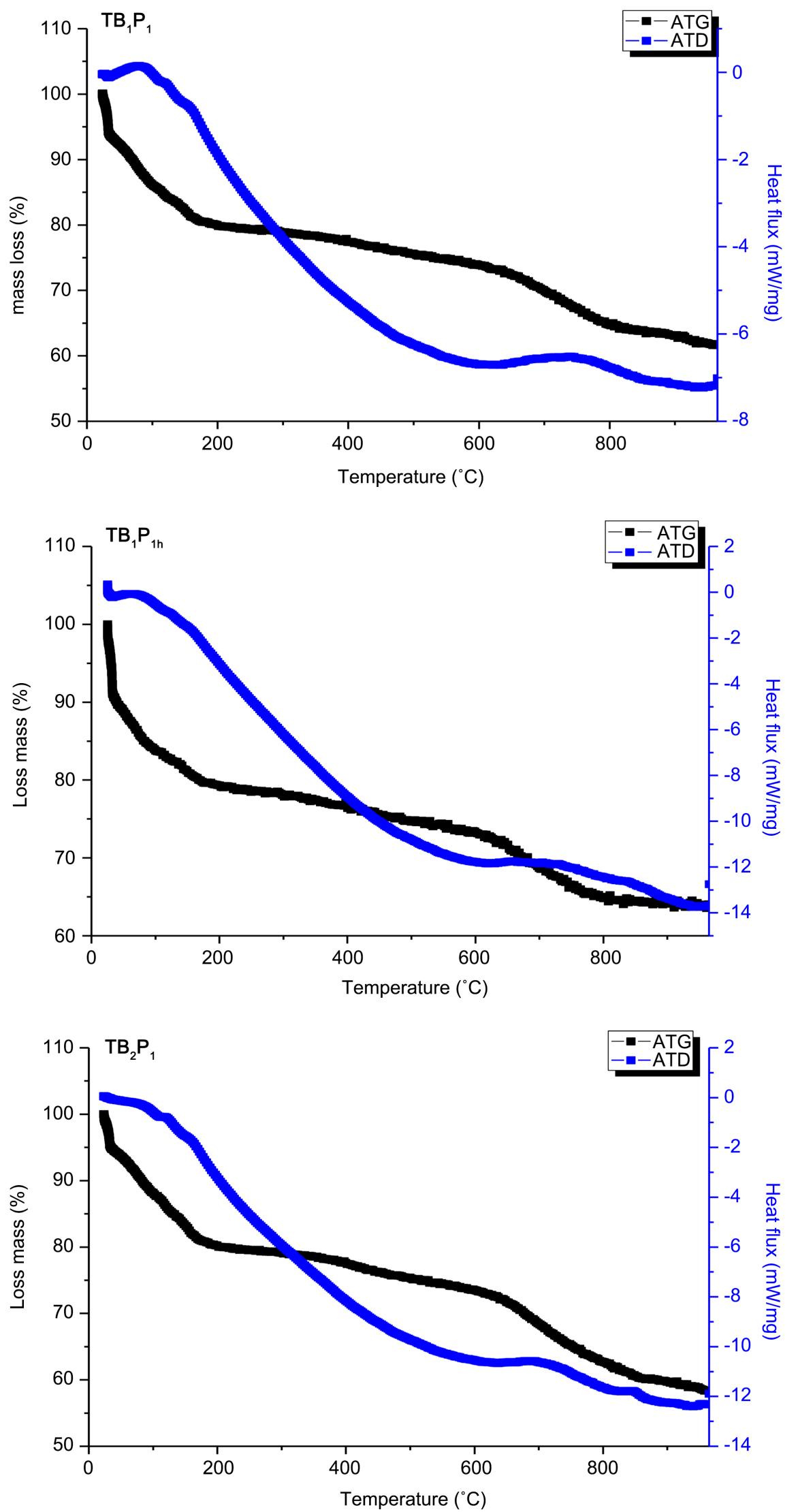

Figure 5. TGA/DTA curves for composite activated carbons $\mathrm{TB}_{1} \mathrm{P}_{1}, \mathrm{~TB}_{1} \mathrm{P}_{1 \mathrm{~h}}$ and $\mathrm{TB}_{2} \mathrm{P}_{1}$. 


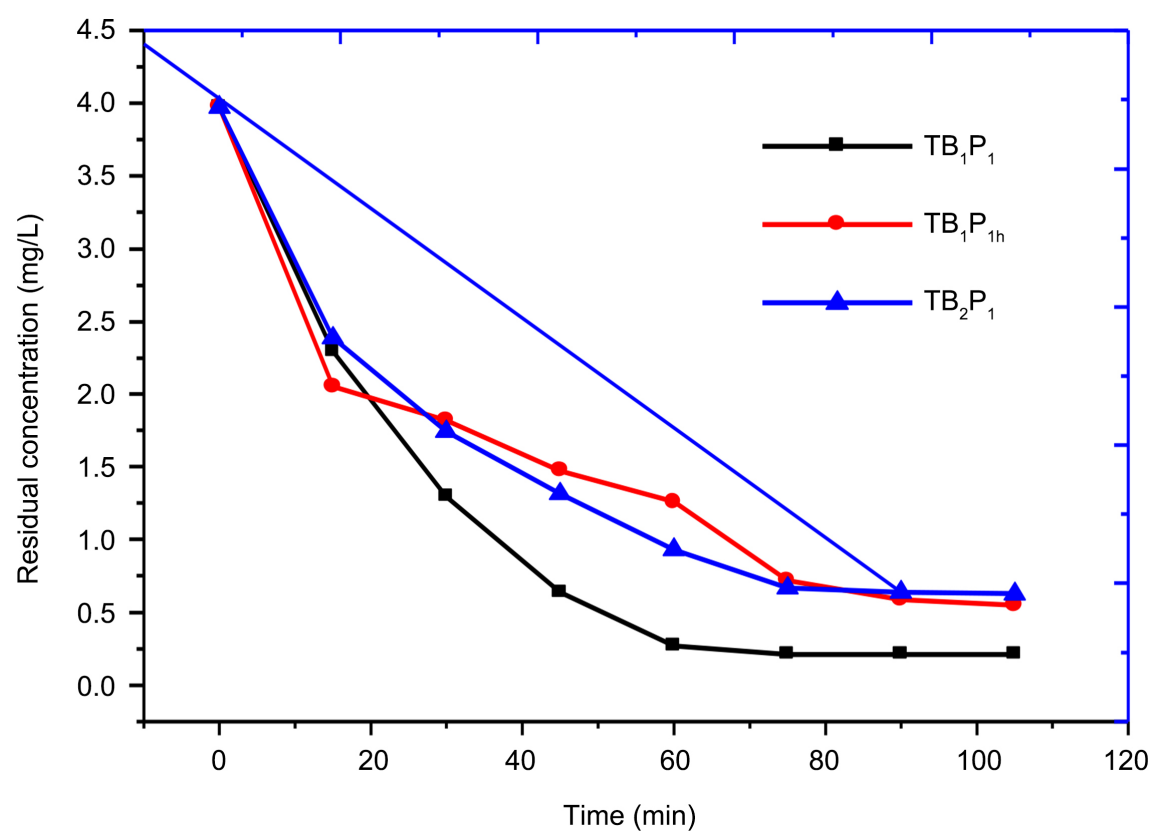

Figure 6. The effect of the contact time on the retention of indigo carmine ( $V=20 \mathrm{~mL}$ $\mathrm{pH}=4.7$ mass $=0.6 \mathrm{~g}$ ).

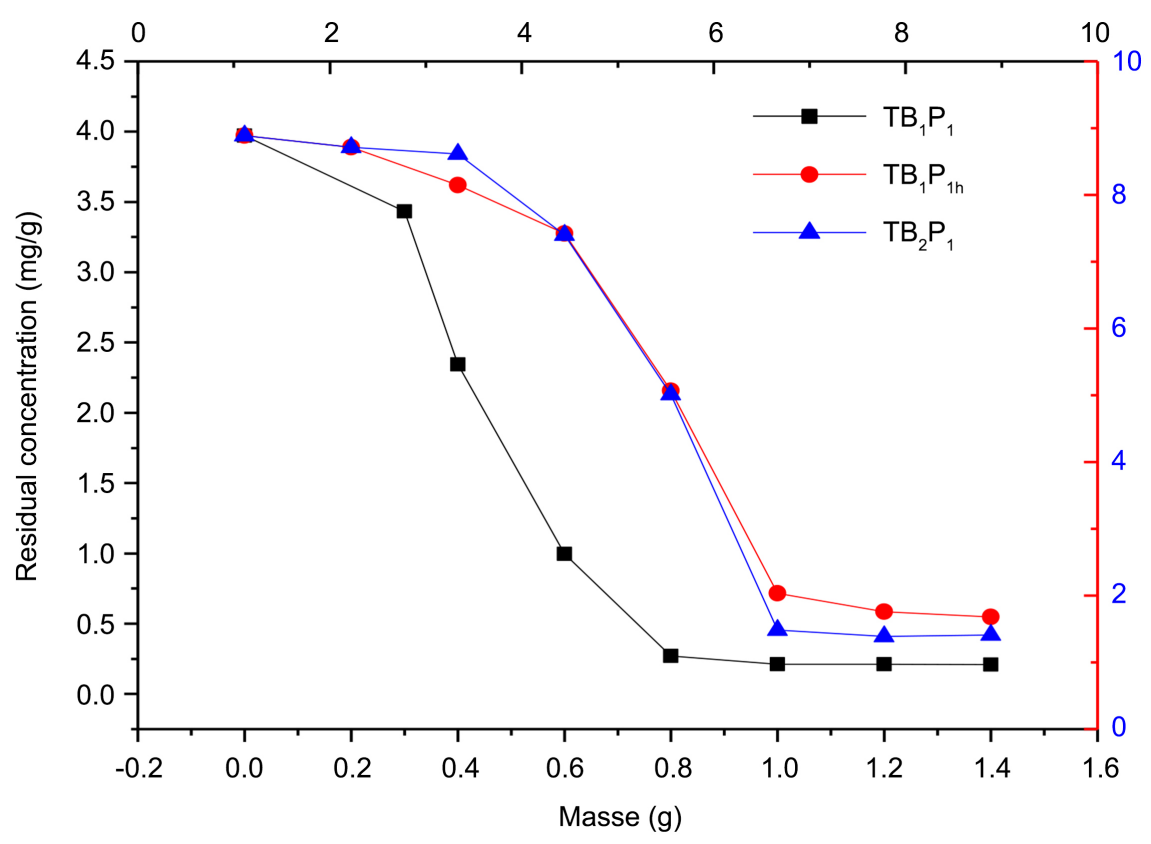

Figure 7. The effect of the mass of the adsorbent on the retention of indigo carmine dye.

\subsubsection{Effect of Initial Pollutant Concentration}

In Figure 8 the adsorption capacity of activated carbon increases with the increase in the concentration of indigo carmine before reaching an equilibrium with maximum adsorbed amounts of 78.3, 67.7 and $77.51 \mathrm{mg} / \mathrm{g}$ respectively for $\mathrm{TB}_{1} \mathrm{P}_{1}, \mathrm{~TB}_{1} \mathrm{P}_{1 \mathrm{~h}}$ and $\mathrm{TB}_{2} \mathrm{P}_{1}$. This can be explained by the fact that the diffusion of dye molecules to the surface of the adsorbent is accelerated as the dye concentration increases. Also, if the initial concentration of dye is low, the molecules ad- 
sorb only on the surface to form a monolayer. On the other hand, when the initial concentration is high, there will consequently be more molecules which will diffuse towards the surface of the sites of the particles of the adsorbents [35] [36].

\subsection{Study of the Isotherm and the Retention Kinetics of the Dye}

The isothermal models and kinetic equilibria used are grouped together in the Table 1 [37].

\subsubsection{Kinetic Models}

In order to understand the rate mechanism that controls the adsorption of indigo carmine by prepared activated carbons, pseudo-first and pseudo-second order kinetic models were exploited.

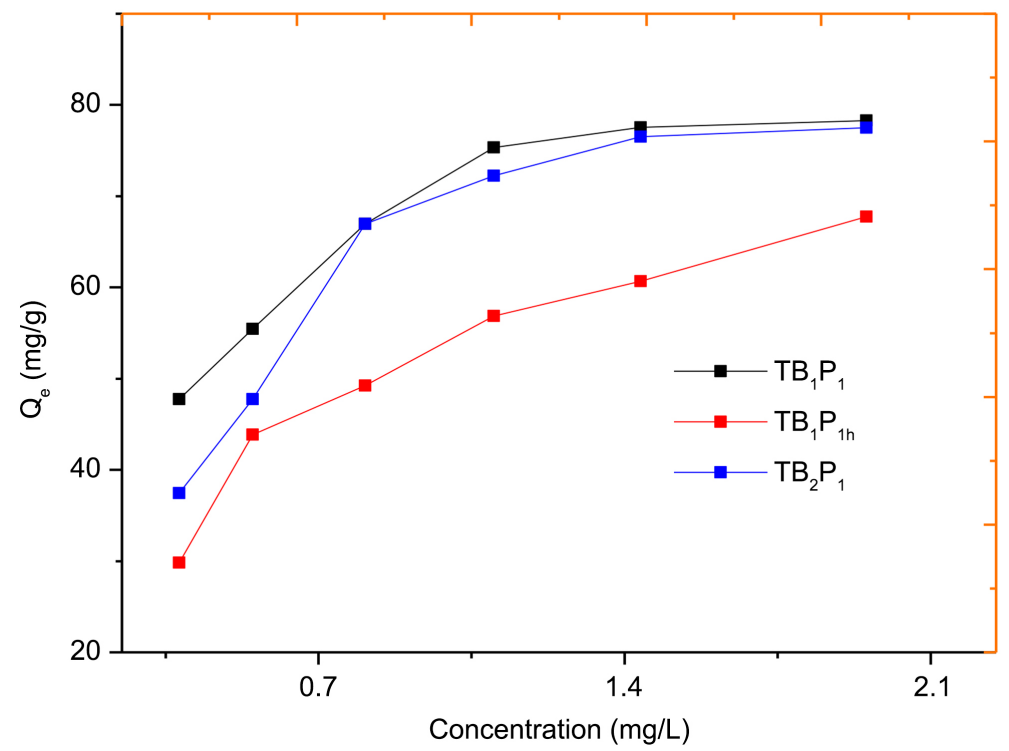

Figure 8. Effect of the initial concentration on the quantity of indigo carmine dye adsorbed $(m=0.6 \mathrm{~g} ; \mathrm{pH}=4.7 ; V=20 \mathrm{~mL}$; Time $=30 \mathrm{~min}$ ).

Table 1. Data on isotherms and kinetic equilibria used.

\begin{tabular}{|c|c|c|}
\hline Equations name & Equations & Description \\
\hline Pseudo-first-order & $\ln \left(Q_{e}-Q_{t}\right)=\ln Q_{e}-K_{1} t$ & $\begin{array}{c}Q_{e} \text { et } Q_{t} \text { respectively are quantities adsorbed } \\
\text { at euilibrium and at the time } t(\mathrm{mg} / \mathrm{g})\end{array}$ \\
\hline Pseudo-second-order & $\frac{t}{Q_{t}}=\frac{1}{K_{2} Q_{e}^{2}}+\frac{t}{Q_{e}}$ & $\begin{array}{l}t \text {. contact time }(\mathrm{min}) ; K_{1} \text { et } K_{2} \text { are respectively } \\
\text { rate contant of first and second order }\left(\mathrm{min}^{-1}\right) \text {. }\end{array}$ \\
\hline Langmuir & $\frac{1}{Q_{e}}=\frac{1}{Q_{m} K_{L} C_{e}}+\frac{1}{Q_{m}}$ & $\begin{array}{c}C_{e} \text { and } Q_{e} \text { are the concentration and amount } \\
\text { at equilibrium; } K_{L} \text { : direct measure of the } \\
\text { intensity of the adsorption process; } \\
Q_{m}: \text { maximum adsorption capacity. }\end{array}$ \\
\hline Freundlich & $\ln Q_{e}=\frac{1}{n} \ln C_{e}+\ln K_{F}$ & $\begin{array}{c}K_{F}: \text { adsorption capacity; } n \text { : intensity of } \\
\text { adsorption; } 1 / n=0 \text { irreversible; } \\
1 / n>1 \text { unfavorable } 0<1 / n<1 \text { favorable. }\end{array}$ \\
\hline
\end{tabular}


The results in Figure 9 and Table 2 show correlation coefficients greater than $0.9\left(R^{2}>0.9\right)$. These results are in agreement with a multilayer adsorption on the surface of the different materials. This involves van der Waal-type interactions between the dye and the various carbons, thus demonstrating a physical adsorption between the adsorbate and the adsorbent.

As for pseudo-second order kinetic models (Figure 10), the hypothesis is that adsorption is proportional to the number of occupied sites. Results indicating correlation coefficients $R^{2}>0.95$; shows that this model applies well in the adsorbent/dye systems studied. It is also noted that the values of the constants $K_{2}$ are almost identical for the three adsorbents. Likewise, the quantities calculated at equilibrium are close to the experimental values in Table 2 . The low values of $K_{2}$ describe a competition between the active sites [38]. In view of these results, we can say that the pseudo-second order model is best suited to model the adsorption of indigo carmine on adsorbents. This model highlights the chemical interactions (covalent bond) between the adsorbate and the adsorbent. The adsorption is monolayer and we can say that chemical adsorption dominates the process of adsorption of indigo carmine on the different activated carbons.

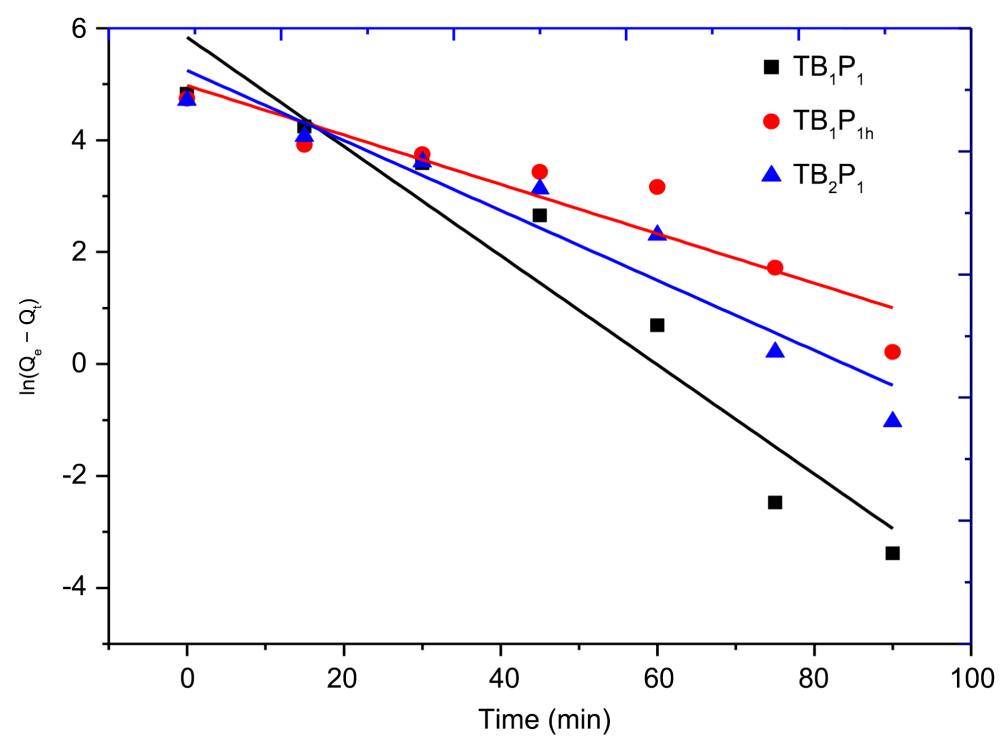

Figure 9. Pseudo-first kinetic order kinetics of indigo carmine adsorption (mass of adsorbent $0.6 \mathrm{~g} ; 20 \mathrm{~mL}, \mathrm{pH}=4.7$ ).

Table 2. Calculated and experimental values of pseudo-first and second order.

\begin{tabular}{cccccccccc}
\hline & \multicolumn{3}{c}{ pseudo-first order } & \multicolumn{3}{c}{ pseudo-second order } \\
\cline { 2 - 9 } Absorbants & $\begin{array}{c}Q_{e}(\mathrm{exp}) \\
(\mathrm{mg} / \mathrm{g})\end{array}$ & $\begin{array}{l}Q_{e}(\mathrm{cal}) \\
(\mathrm{mg} / \mathrm{g})\end{array}$ & $K_{1}$ & $R^{2}$ & $\begin{array}{c}Q_{e}(\mathrm{exp}) \\
(\mathrm{mg} / \mathrm{g})\end{array}$ & $\begin{array}{c}Q_{e}(\mathrm{cal}) \\
(\mathrm{mg} / \mathrm{g})\end{array}$ & $K_{2}$ & $R^{2}$ \\
\hline $\mathrm{TB}_{1} \mathrm{P}_{1}$ & 125.40 & 342.639 & -0.098 & 0.92845 & 125.402 & 123.609 & 0.00060 & 0.95493 \\
$\mathrm{~TB}_{1} \mathrm{P}_{1 \mathrm{~h}}$ & 114.10 & 144.785 & -0.044 & 0.87578 & 114.108 & 140.252 & 0.00062 & 0.96339 \\
$\mathrm{~TB}_{2} \mathrm{P}_{1}$ & 118.449 & 189.519 & -0.063 & 0.92185 & 118.449 & 124.223 & 0.00061 & 0.96199 \\
\hline
\end{tabular}




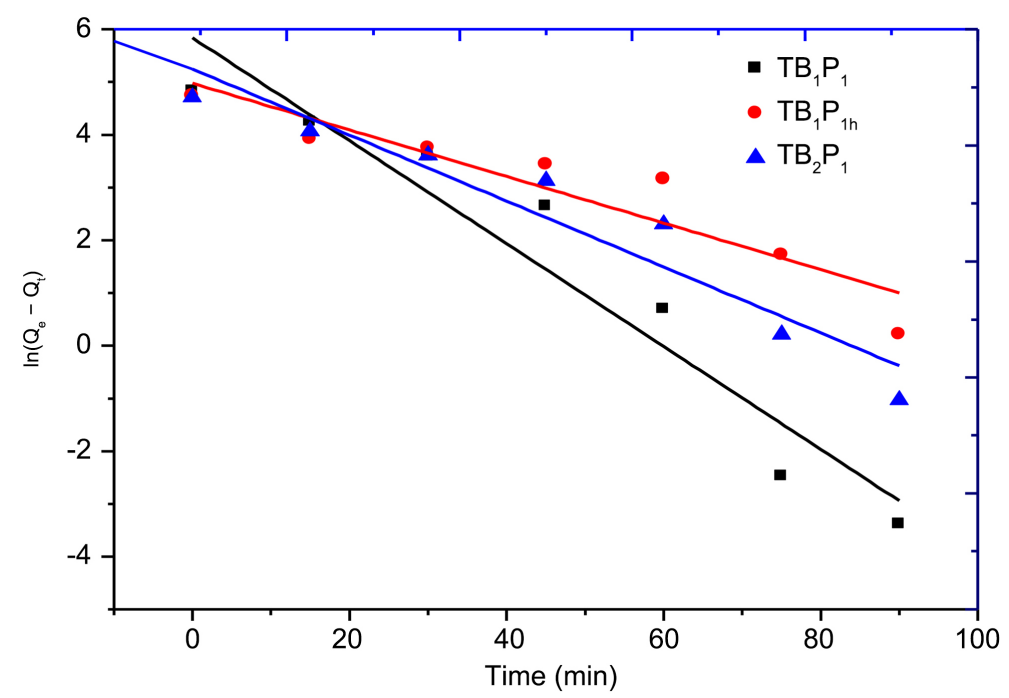

Figure 10. Pseudo-second kinetic order kinetics indigo carmine adsorption (mass of adsorbent $=0.6 \mathrm{~g} ; 20 \mathrm{~mL}, \mathrm{pH}=4.7$ ).

Although both processes agree with adsorption, the one that best defines it is the characteristic pseudo second-order pattern of chemisorption at the surfaces of activated carbon samples.

\subsubsection{Adsorption Isotherms}

The Freundlich and Langmuir models were used to interpret the surface heterogeneity of different activated carbons during the adsorption of indigo carmine. Actually, the empirical Freunlich equation with two parameters $K_{F}$ and $1 / \mathrm{n}$ (Freundlich coefficients), takes into account an exponential distribution of the energies of the adsorption sites on the surface of the solid and an adsorption in localized sites [39]. The adsorption isotherms of the three adsorbents are shown in Figure 11 and Figure 12. The 1/ $n$ values obtained are less than 1, which indicates that the adsorption is normal on these materials. These values of $1 / n$ support the hypothesis of the heterogeneity of the surface of the different adsorbents. The constant $K_{F}$ is a rough indicator of the adsorption capacity while $1 / \mathrm{n}$ is a function of the adsorption affinity in the process.

However, it can be seen that the values of $R^{2}$ for $\mathrm{TB}_{1} \mathrm{P}_{1}$ and $\mathrm{TB}_{2} \mathrm{P}_{1}$ are less than 0.96, which limits the use of the Freundlich model for the description of the adsorption of indigo carmine on the two adsorbents [34]. On the other hand, the model is more favorable for the sample $\mathrm{TB}_{1} \mathrm{P}_{1 \mathrm{~h}}\left(R^{2}=0.98\right)$.

However, Langmuir's thermodynamic model is theoretically applicable only in the case of single-layer, localized, homogeneous adsorption sites of equal energies and without lateral interaction between the adsorbed particles [39]. The Langmuir isotherm describes the adsorption of indigo carmine on different carbons with the correlation coefficients $R^{2}>0.97$. The essential characteristic of this isotherm is its separation factor which is a dimensionless constant expressed by:

$$
R_{L}=\frac{1}{1+K_{L} C_{0}}
$$




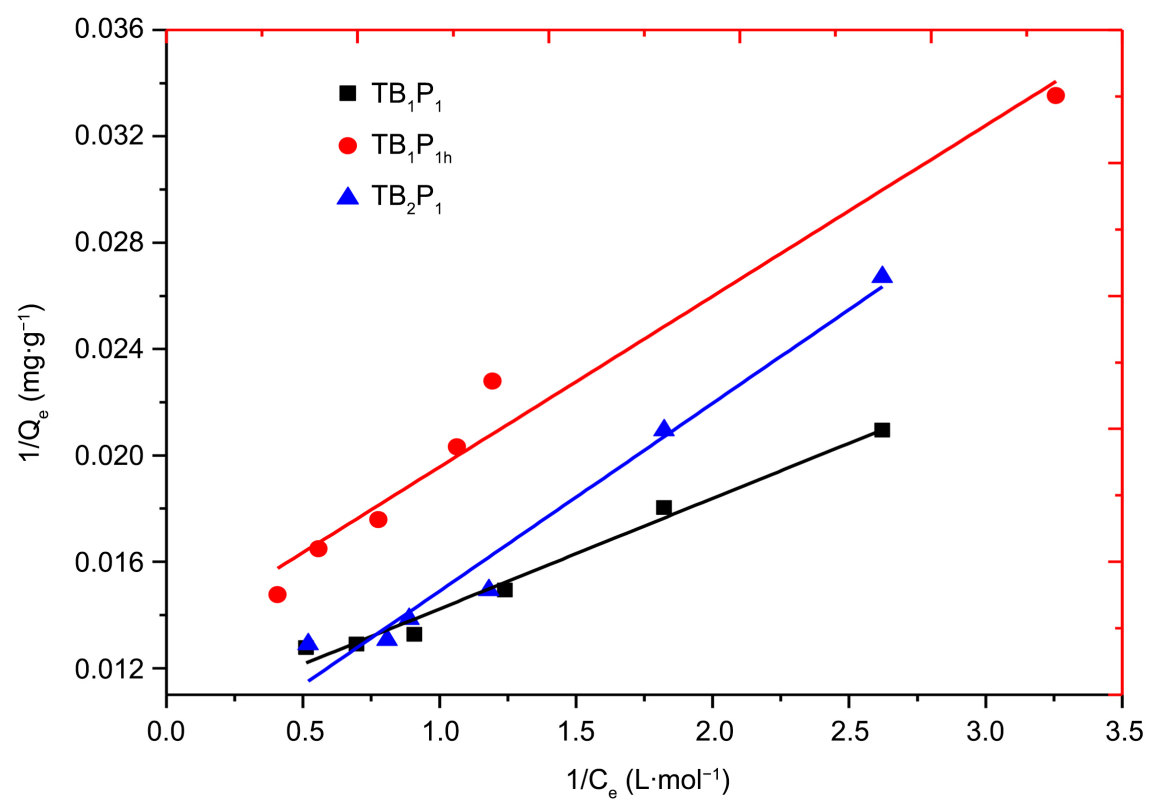

Figure 11. Linear transformation of Langmuir.

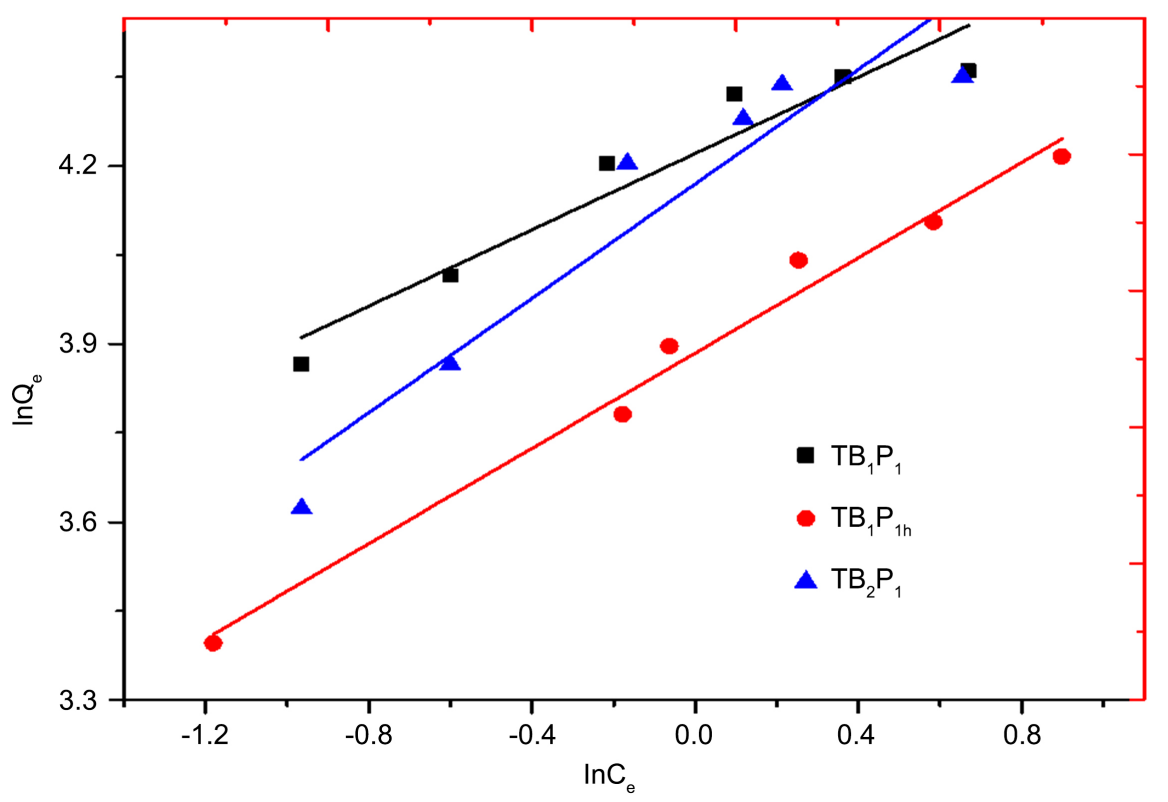

Figure 12. Linear transformation of Freundlich.

For adsorption to be favourable, the separation factor $R_{L}$ should provide values ranging between $0<R_{L}<1$. The values obtained for these factors are: 0.10 ; 0.11 and 0.18 respectively for $\mathrm{TB}_{1} \mathrm{P}_{1} ; \mathrm{TB}_{1} \mathrm{P}_{1 \mathrm{~h}}$ and $\mathrm{TB}_{2} \mathrm{P}_{1}$. These values show that the quantity adsorbed $Q_{m}$ for $\mathrm{TB}_{2} \mathrm{P}_{1}$ is higher than that of $\mathrm{TB}_{1} \mathrm{P}_{1}$ which is in turn higher than that of $\mathrm{TB}_{1} \mathrm{P}_{1 \mathrm{~h}}$ (Table 2). Therefore, the sample $\mathrm{TB}_{2} \mathrm{P}_{1}$ shows a greater affinity to adsorb the dye on a single layer relative to $\mathrm{TB}_{1} \mathrm{P}_{1} ; \mathrm{TB}_{1} \mathrm{P}_{1 \mathrm{~h}}$ respectively. In view of the different experimental values obtained, we can say that Langmuir's model aptly describes the phenomenon of dye adsorption on the 3 adsorbents. 
Hence strong chemical adsorption dominates the process on a single layer surface.

\section{Conclusion}

Plastic waste and the banana stem were used in the preparation of activated charcoals by steam activation, for the removal of indigo carmine in aqueous media. The materials obtained had non-negligible specific surfaces, and various surface groups. This allows them to adsorb indigo carmine with a percentage of $94 \%$ as well as a maximum amount adsorbed of $127.55 \mathrm{mg} / \mathrm{g}$ according to Langmuir. The pseudo-second order kinetic model best defined the absorption phenomenon. That is, adsorption is chemical in nature, single-layered on homogeneous surface.

\section{Conflicts of Interest}

The authors declare no conflicts of interest regarding the publication of this paper.

\section{References}

[1] Batzias, F.A. and Sidiras, D.K. (2007) Dye Adsorption by Prehydrolysed Beech Sawdust in Batch and Fixed-Bed Systems. Bioresource Technology, 98, 1208-1217. https://doi.org/10.1016/j.biortech.2006.05.020

[2] Muñoz, I., Gómez-Ramos, M.J., Agüera, A., García-Reyes, J.F., Molina-Días, A. and Fernández-Alba, R. (2009) Chemical Evaluation of Contaminants in Wastewater Effluents and the Environmental Risk of Reusing Effluents in Agriculture, $\operatorname{Tr} A C$ Trends in Analytical Chemistry, 28, 676-694. https://doi.org/10.1016/j.trac.2009.03.007

[3] Minxia L., Hongtao W., Shengju W., Fengting L. and Pengdan, Z. (2012) Adsorption of Hazardous Dyes Indigo Carmine and Acid Red on Nanofiber Membranes. The Royal Society of Chemistry, 2, 900-907. https://doi.org/10.1039/C1RA00546D

[4] Ammar, S., Abdelhedi, R., Flox, C., Arias, C. and Brillas, E. (2006) Electrochemical Degradation of the Dye Indigo Carmine at Boron-Doped Diamond Anode for Wastewaters Remediation. Environmental Chemistry Letters, 4, 229-233. https://doi.org/10.1007/s10311-006-0053-2

[5] Mittal, A., Mittal, J. and Kurup, L. (2007) Utilization of Hen Feathers for the Adsorption of Indigo Carmine from Simulated Effluents. Journal of Environmental Protection, 1, 92-100.

[6] Banat I.M., Nigam P., Singh, D. and Marchant, R. (1996) Microbial Decolorization of Textile-Dye-Containing Effluents: A Review. Bioresource Technology, 58, 217-227. https://doi.org/10.1016/S0960-8524(96)00113-7

[7] Hajati S., Ghaedi M., Karimi F., Barazesh B., Sahraei R. and Daneshfar, A. (2014) Competitive Adsorption of Direct Yellow 12 and Reactive 12 on ZnS:Mn Nanoparticles Loaded on Activated Carbon as Novel Adsorbent. Journal of Industrial Engineering Chemistry, 20, 564-571. https://doi.org/10.1016/j.jiec.2013.05.015

[8] Ankoro, N.O., Kouotou, D., Belibi, B.P.D., Ndi, J.N. and Ketcha, J.M. (2016) Removal of Indigo Carmine Dye (ic) by Batch Adsorption Method onto Dried Cola Nut Shells and Its Active Carbon from Aqueous Medium. International Journal of 
Engineering Sciences \& Research Technology, 5, 874-887.

[9] Giri, A.K., Banerjee, T.S., Talukder, G. and Sharma, A. (1986) Effects of Dyes (Indigo Carmine, Metanil Yellow, Fast Green FCF) and Nitite in Vivo on Bone Marrow Chromosomes of Mice. Cancer Letters, 30, 315-320.

https://doi.org/10.1016/0304-3835(86)90056-X

[10] Yang, J., Monk, T.G. and White, P.F. (1991) Acute Hemodynamic Effects of Indigo Carmine in the Presence of Compromised Cardiac Function. Journal of Clinical Anesthesia, 3, 320-323. https://doi.org/10.1016/0952-8180(91)90229-G

[11] Naitoh, J.M.D., Brendan, M.D. and Fox, M. (1994) Severe Hypotension, Bronchospasm and Urticaria from Intravenous Indigo Carmine. Urology Journal, 44, 271-272. https://doi.org/10.1016/S0090-4295(94)80149-5

[12] Othmani, A., Kesraoui, A. and Seffen, M. (2017) The Alternating and Direct Current Effect on the Elimination of Cationic and Anionic Dye from Aqueous Solutions by Electrocoagulation and Coagulation Flocculation. Euro-Mediterranean Journal for Environmental Integration, 2, 1-12. https://doi.org/10.1007/s41207-017-0016-y

[13] Indra, D.M., Nidhi, T. and Chandra, K.T. (2013) Treatment of Indigo Carmine Dye Bearing Wastewater by Electrocoagulation. 2nd International Conference on Environment, Agriculture and Food Sciences, Kuala Lumpur, August 25-26 2013, 86-90.

[14] Sayed, E. (2013) Removal of Indigo Carmine Dye from Synthetic Wastewater by Electrochemical Oxidation in a New Cell with Horizontally Oriented Electrodes. International Journal of Electrochemical Science, 8, 846 -858.

[15] Liu, C.Y., Wang, G.H., Sui, W.J., An, L.L. and Si, C.L. (2017) Preparation and Characterization of Chitosan by a Novel Deacetylation Approach Using Glycerol as Green Reaction Solvent. ACS Sustainable Chemistry \& Engineering, 5, 4690-4698. https://doi.org/10.1021/acssuschemeng.7b00050

[16] Sani, S.B., Ahed, J.A., Bashir, S.S. and Abdulhadi, M. (2018) Photocatalytic Degradation of Indigo Carmine in Aqueous Solutions by the Antibacterial Agent Pefloxacin and UVA. Journal of Scientific and Technical Research, 5, 4903-4909. https://doi.org/10.26717/BJSTR.2018.05.001275

[17] Fatombi, K.J., Idohou, A.E., Osseni, A.S., Agani, I., Neumeyer, D., Verelst, M., Mauricot, R. and Aminou, T. (2019) Adsorption of Indigo Carmine from Aqueous Solution by Chitosan and Chitosan/Activated Carbon Composite: Kinetics, Isotherms and Thermodynamics Studies. Fibers and Polymers, 20, 1820-1832. https://doi.org/10.1007/s12221-019-1107-y

[18] Zeinab, H.D., Seyyed, S.M. and Mehdi, D.E. (2019) Enhanced Adsorptive Removal of Indigo Carmine Dye Performance by Functionalized Carbon Nanotubes Based Adsorbents from Aqueous Solution: Equilibrium, Kinetic, and DFT Study. Journal of Nanostructure in Chemistry, 9, 323-334.

https://doi.org/10.1007/s40097-019-00321-0

[19] Machrouhi, A., Alilou, A., Farnane, M., El Hamidi, S., Sadiq, M., Abdennouri, M., Tounsadi, H. and Barka, N. (2019) Statistical Optimization of Activated Carbon from Thapsiatranstagana Stems and Dyes Removal Efficiency Using Central Composite Design. Journal of Science: Advanced Materials and Devices, 4, 544-553. https://doi.org/10.1007/s40097-019-00321-0

[20] Sumalatha, B., Kumar, P.Y., Kumar, K.K., Babu, J.D., Narayana, V.A, Das, M.K. and Venkateswarulu, T.C. (2014) Removal of Indigo Carmine from Aqueous Solution by Using Activated Carbon. Research Journal of Pharmaceutical, Biological and Chemical Sciences, 5, 912-922.

[21] Ramesh, T.N., Kirana, D.V., Mohana, K.T.N. and Ashwini, A. (2014) Adsorption 
Studies of Indigo Carmine dye by Magnesium Oxide. Inernational Journal of Science Research, 1, 495-501.

[22] Gutierrez-Segura, E., Solache-Rios, M. and Colin-Cruza, A. (2009) Sorption of Indigo Carmine by a Fe-Zeolitic Tuff and Carbonaceous Material from Pyrolyzed Sewage Sludge. Journal of Hazardous Materials, 170, 1227-1235.

https://doi.org/10.1016/j.jhazmat.2009.05.102

[23] Abdoul, N.R., Abdoul, W., Mountapmbeme, P.K., Abdelaziz, B., Kouotou, D. and Abdelrani, Y. (2017) Removal of Micro Pollutants from Aqueous Solution Using Activated Carbons from PET Waste. Canadian Journal of Pure and Applied Sciences, 11, 4131-4140.

[24] Michelezsl (2017) A Million Bottles a Minute: World's Plastic Binge 'as Dangerous as Climate Change'. Article The Guardian.

[25] Esfandiari, A., Kaghazchi, T. and Soleimani, M. (2011) Preparation of High Surface Area Activated Carbon from Polyethyleneterephthalate (PET) Waste by Physical Activation. Research Journal of Chemistry and Environment, 15, 433-437.

[26] Abreu, A. and Pedrott, L.M. (2019) Les microplastiques dans les océans: Les solutions sont à terre. La Revue de l'Institut Veolia, 112.

[27] Zaidi, A.G., Mohd, S.Y. and Jeyashelly, A. (2016) Development of Activated Carbon from Banana Pseudo-Stem via Single Step of Chemical Activation. AIP Conference Proceedings.

[28] Dresselhaus, M.S., Jorio, A., Hofmann, M., Dresselhaus, G. and Saito, R. (2010) Perspectives on Carbon Nanotubes and Graphene Raman Spectroscopy. Nano Letters, 10, 751-758. https://doi.org/10.1021/nl904286r

[29] Chen, H., Zhao, Z.Z. and Qi, P.R. (2019) Sulphur-Doped Banana Peel-Derived Activated Carbon as Electrode Materials for Supercapacitors. International Journal of Nanomanufacturing, 15,181-195. https://doi.org/10.1504/IJNM.2019.097253

[30] Taer, E., Taslim, R., Mustika, W.S., Kurniasih, B., Agustino, Afrianda, A. and Apriwandi (2018) Production of an Activated Carbon from a Banana Stem and Its Application as Electrode Materials for Supercapacitors. International Journal of Electrochemical Science, 13, 8428-8439. https://doi.org/10.20964/2018.09.55

[31] Zaidi, A.G., Mohd, S.Y., Nastaein, Q.Z., Mohd, F.M.A.Z. and Jeyashelly, A. (2017) Optimization of Preparation Conditions for Activated Carbon from Banana Pseudo-Stem Using Response Surface Methodology on Removal of Color and COD from Landfill Leachate. Waste Management, 62, 177-187.

[32] Ayral, C. (2009) Elimination de polluants aromatiques par oxydation catalytique sur charbon actif. Thèse de Doctorat, Institut National Polytechnique de Toulouse, France, 227.

[33] Tripti, B.G. and Dilip, H.D. (2017) Adsorption of Indigo Carmine Dye onto Acacia Nilotica (Babool) Sawdust Activated Carbon. Journal of Hazardous, Toxic, and Radioactive Waste, 21. https://doi.org/10.1061/(ASCE)HZ.2153-5515.0000365

[34] Al-Ghouti, M.A., Khraisheh, M., Allen, S.J. and Ahmad, M.N. (2003) The Removal of Dyes from Textile Waste Water: A Study of the Physical Characteristics and Adsorption Mechanisms of Diatomaceous Earth. Journal of Environmental Management, 69, 229-235. https://doi.org/10.1016/j.jenvman.2003.09.005

[35] Garg, V.K., Gupta, R., Yadav, A.B. and Kumar, R. (2003) Dye Removal from Aqueous Solution by Adsorption on Treated Sawdust. Bioresource Technology. 89, 121-124. https://doi.org/10.1016/S0960-8524(03)00058-0

[36] Ngaha, M.C.D., Njanja, E.E., Doungmo, G., Kamdem, A.T. and Tonle, I.K. (2019) 
Indigo Carmine and 2,6-Dichlorophenolindophenol Removal Using Cetyltrimethylammonium Bromide-Modified Palm Oil Fiber: Adsorption Isotherms and Mass Transfer Kinetics. International Journal of Biomaterials, 2019, 1-19. https://doi.org/10.1155/2019/6862825

[37] Chen, H., Zhao, J. and Dai, G. (2011) Silkworm Exuviae-A New Nonconventional and Low-Cost Adsorbent for Removal of Methylene Blue from Aqueous Solutions. Journal of Hazardous Materials, 186, 1320-1327.

https://doi.org/10.1016/j.jhazmat.2010.12.006

[38] Serpaud, B., Al-Sukry, R., Casteigneau, M. and Matejka, G. (1994) Adsorption des métaux lourds $(\mathrm{Cu}, \mathrm{Zn}, \mathrm{Cd}$ et $\mathrm{Pb})$ par les sediments superficiels d'un cours d'eau: rôle du $\mathrm{pH}$, de la température et de la composition du sédiment. Revue Des Sciences De L'eau, 7, 343-365. https://doi.org/10.7202/705205ar

[39] Carvalho, M.F., Duque, A.F., Gonçalves, I.C. and Castro, P.L.M. (2007) Adsorption of Fluorobenzene onto Granular Activated Carbon: Isotherm and Bioavailability Studies. Bioresource Technology, 98, 3424-3430.

https://doi.org/10.1016/j.biortech.2006.11.001 